\title{
LETRAS SIN SOL: LA VISIÓN DE FLANDES EN DOS POETAS SOLDADOS DEL RENACIMIENTO ESPAÑOL ${ }^{1}$
}

\author{
Clara Marías Martínez \\ Universidad Complutense de Madrid
}

«mientras el pecho al desenvuelto Marte tan libre di que sin mi daño puede, hablando la verdad, ser muda el arte» Aldana «y así, aunque capitán de infantería, me entretuvo Virgilio y Garcilaso» Rey de Artieda

\footnotetext{
1 Recibido: 26/I/2010 Aceptado: 15/III/2010
}

Este artículo parte de la comunicación presentada en el I Congreso de la Asociación de Jóvenes Investigadores Filólogos (Universidad Complutense, Octubre de 2007). Su reelaboración y ampliación es fruto del apoyo de la Beca de Formación de Profesorado del Ministerio de Educación. Agradezco al Dr. Alonso Miguel (UCM) el haberme despertado el interés por los poetas soldados y sus andanzas flamencas, así como sus sugerencias. 


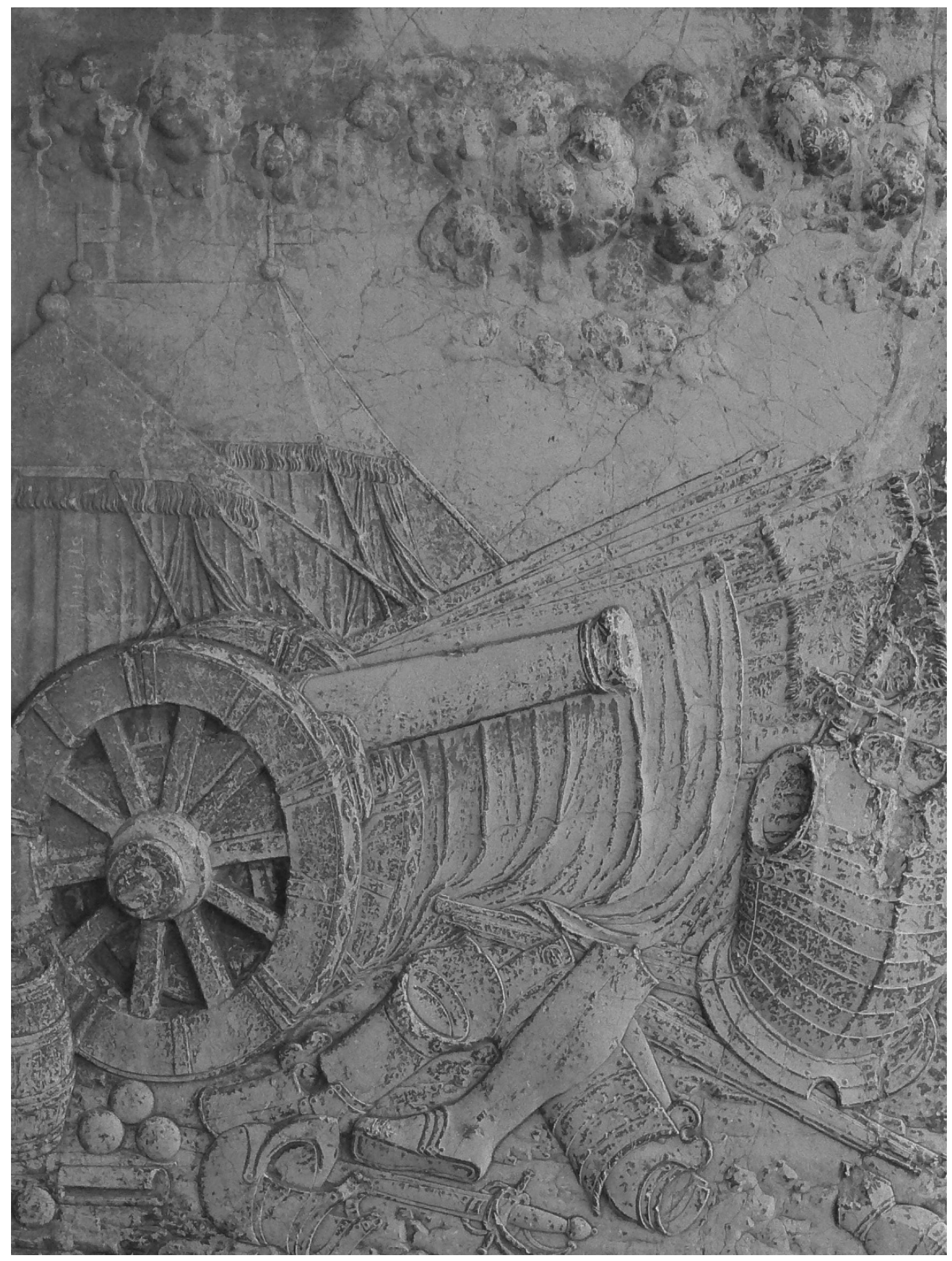




\section{Panorama de las causas de la rebelión en Flandes.}

La extensión y los variados intereses de los territorios dominados por Felipe II a raíz de su herencia hacían muy difícil su convivencia y permanencia dentro de la Monarquía Hispánica; pero a pesar de las dificultades para abarcar el control de todos ellos (era reclamado en Inglaterra, Castilla y Flandes por el peligro de insurrecciones y las enormes deudas), el rey era partidario de mantener todas sus posesiones unidas y de fomentar la solidaridad entre ellas. Por ello, al reanudarse la guerra contra Francia en el frente norte, exigió a los Países Bajos mayores subsidios, argumentando que de «todas partes es bien que nos ayudemos». ${ }^{2} \mathrm{El}$ intento de imponer unos impuestos fijos y controlarlos provocó el rechazo de los Estados Generales, que comenzaron a socavar la autoridad real. Las malas cosechas, las epidemias y el desgaste que suponía abastecer y alojar a los ejércitos alimentaron el descontento.

Otra de las raíces del conflicto fue de índole religiosa. La extensión del calvinismo por los Países Bajos era inaceptable para Felipe II, que trató de frenarla con decretos condenatorios, con la Inquisición, y con una reforma de las sedes episcopales, medidas que indignaron a la nobleza flamenca, bien porque las consideraban intervencionistas, bien porque defendían una mayor libertad religiosa. A pesar de la preocupación del rey por solucionar los problemas financieros y religiosos -decía que derramaría su sangre de buena gana si con ello remediara las necesidades de las provincias ${ }^{3}$ - cada vez era juzgado con mayor recelo. En agosto de 1566 la oposición de la nobleza, la burguesía y los calvinistas, y el hambre, prendieron en la población; y estalló la violencia, canalizada en la quema de iglesias e imágenes católicas.

Ante el deterioro de la situación cabían dos opciones: la moderación y mayor tolerancia (encarnadas en Margarita de Parma) o la represión feroz. El rey eligió esta última y encargó la tarea al duque de Alba, que reunió un ejército de sesenta mil hombres -la mayor parte veteranos de los tercios que se hallaban en Italia- con el que llegó a Bruselas en agosto de 1567. Una vez allí, creó el Tribunal de Tumultos, con el que trató de imponer el orden juzgando a los herejes y a los opositores políticos. Mientras los condes de Egmont y Horn fueron condenados, Guillermo de Orange logró huir a Alemania, para desde allí formar un ejército y atacar a los tercios españoles. La actuación del duque de Alba aumentó el resentimiento de la población contra las tropas reales; y la tensión creció al establecerse tres impuestos fijos que gravaban las ventas y las rentas, acabando con los privilegios de los más ricos.

2 M.J. Rodríguez-Salgado, Un imperio en transición. Carlos V, Felipe II y su mundo, Barcelona, Crítica, 1992, p. 285.

3 Idem, p. 527. 
Así comenzó el conflicto que ahogó al Imperio durante ochenta años y marcó el devenir de la Monarquía Hispánica. La inquietud suscitada por la rebelión, y la conciencia de la importancia estratégica de la región amenazada ${ }^{4}$ se reflejaron en la literatura del momento, como muestran estos versos de Francisco de Aldana dirigidos a Felipe II:

Esta seguridad, según se entiende,
mal podemos creer, pues ya se apresta,
ya, contra tus decretos, se defiende
la flamenca región, que tanto cuesta;
ya de hereje furor todo se enciende,
alza de rebelión la fiera cresta,
muéstrase toda armada la campaña
que la Schelda y la Mosa riega y baña [...]
Esta sola región es puerta y llave
de dos cercanos reinos y un imperio $[. . .]^{5}$

Este trabajo sigue la línea de aquellos que han estudiado la representación de las guerras de Flandes en la literatura del Siglo de Oro, especialmente en el teatro, ${ }^{6}$ pero se detiene en la poesía, centrándose en dos autores cuya visión del conflicto es más cercana, puesto que son testigos del mismo; y enfocando un género, la epístola en verso, que por sus rasgos ofrece una expresión más directa y personal que la comedia histórica o la crónica. Buceando en las poesías de Francisco de Aldana y de Andrés Rey de Artieda encontramos, por un lado, un testimonio de gran valor tanto histórico como literario de las guerras flamencas; $y$, por otro, la transformación de la imagen y la ideología de los militares que éstas provocaron.

\section{Francisco de Aldana: del orgullo a la desazón.}

La experiencia de Francisco de Aldana en Flandes pertenece a la primera fase del enfrentamiento, inestable y de carácter más civil, pues los habitantes de los Países Bajos aún se dividían entre partidarios de mantener su autonomía dentro de

\footnotetext{
4 Según M. de Pazzis, «Pedro de Valdés y la Armada de Flandes», Cuadernos de Historia Moderna, no 9 (1988), pp. 35-36, «después de las Indias [los Países Bajos] eran el cordón umbilical más importante de Castilla». La necesidad de una fuerza marítima para mantener estos territorios era básica según Aldana, y así lo muestran los diversos intentos de Felipe II por organizarla, que acabaron en fracaso.

5 F. de Aldana, Poesías castellanas completas, Ed. de José Lara Garrido, Madrid, Cátedra, 1985, «Octavas dirigidas al rey don Felipe, nuestro Señor», p. 411, vv. 393-400, y p. 412, vv.409-410. Para todas las citas de este poeta, utilizo dicha edición.

6 Me refiero, por ejemplo, al clásico estudio de Simon A. Vosters, La rendición de Breda en la literatura y el arte de España, London, Tamesis, 1973; o, más recientemente, a las actas Hazañas bélicas y leyenda negra: argumentos escénicos entre España y los Países Bajos: Coloquio Internacional, Béthune, 25-26 de marzo de 2004, o la ponencia de Juan Udaondo “Entre la evocación épica y la crónica de guerra. El sitio de Breda de Calderón de la Barca" expuesta en las XXXIII Jornadas de Teatro Clásico de Almagro.
} 
la Monarquía Hispánica, y defensores de la independencia total. Nacido en 1537,

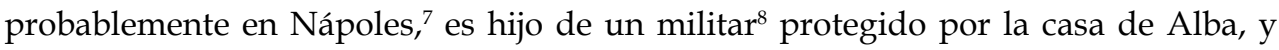
se forma intelectual y militarmente en Florencia, ${ }^{9}$ lo que le marcará profundamente. Parece que su primera intervención bélica fue la batalla de San Quintín, y que llegó a ser capitán de infantería en Italia. Desde allí fue trasladado a Flandes, probablemente con don García de Toledo y parte de las tropas de Nápoles y Lombardía, antes de que llegara el duque de Alba. En sus poemas escritos en Flandes, donde según su hermano Cosme $^{10}$ desarrolló la mayor parte de su vida militar, refleja la vida en la corte de Bruselas del duque, que se rodea de nobles y oficiales; los primeros enfrentamientos directos con los holandeses (Heeiligerlee, Jemmingen), y los penosos sitios a ciudades como Haarlem y Alkmaar. Además, en poemas posteriores expresa su hartazgo de la vida militar, su deseo de descansar y su exigencia de obtener alguna recompensa por sus servicios. Otras huellas del conflicto se encuentran en las octavas dirigidas al rey Felipe II, en las que hace balance de la guerra, y analiza la importancia estratégica de Flandes dentro del Imperio. Es decir, Flandes aparece en Aldana de tres formas: como espacio de espera y lucha, como experiencia que marca un antes y un después en su carrera militar y en su estado anímico, y como grave problema político de su época que le preocupa enormemente. Analizar la presencia de Aldana en Flandes la correspondencia entre su descripción como testigo y los hechos históricos- es tan importante como estudiar la presencia de Flandes en la poesía de Aldana -su visión subjetiva, individual-.

La epístola en verso escrita en Flandes a su hermano Cosme es especialmente ilustrativa. Las características del género, tan importante en el Renacimiento, favorecen

\footnotetext{
7 Para ampliar los datos biográficos del poeta esbozados a continuación remito a la obra de E. L. Rivers, Francisco de Aldana, el divino capitán, Badajoz, Institución de Servicios Culturales, 1955 (para la etapa en Flandes, pp. 53-80), y a la más reciente introducción a las Poesías castellanas completas realizada por Lara Garrido, p. 21 y ss.

8 No sólo su padre (alcaide de varias ciudades napolitanas, escolta de Leonor de Toledo en su boda con Cosme de Medici, y castellano de Livorno y San Miniato), sino también su abuelo materno (en la batalla de Pavía) y su tío paterno (general de artillería en Nápoles), habían alcanzado la fama como militares. Véase E.L. Rivers (1955), pp. 18-20.
}

9 Allí se relaciona con poetas de la corte de los Medici, como Benedetto Varchi (editor de las Prose de Bembo, traductor de Séneca y Boecio, admirador de León Hebreo...), y escribe un soneto circunstancial a la muerte de Leonor de Toledo, que parece el único poema publicado en vida. Véase E.L. Rivers (1955), p. 34-35.

10 Cosme de Aldana dice así: «Mas do más largamente él se detuvo/siguiendo el claro y militar ofiçio/ en Belgia fue, do mucho tiempo estuvo/en sangriento, cruel, fiero exerçitio/do la infidelidad que en sí sostuvo/la rebeldía con claro malefiçio/persiguió días y noches, contrastando/al de Dios y al del Rey contrario vando». Citado por E. L. Rivers (1955), p. 53. En otras octavas especifica el tiempo en que sirvió su hermano y sus dificultades finales: «En Belgia por tres lustros no perfectos/habiendo claramente militado/y en mil heroicos de valor efectos/viéndose ya mil vezes señalado/quando un odio mortal varios afectos/movió para impedille el alto grado» (Rivers, 1955, p. 81). También resulta significativo de la importancia de Flandes en su vida el que allí perdiera a su hermano mayor, también militar, como recoge Aldana en su memorial de 1577 (Rivers, 1955, p. 31). 
la plasmación de los acontecimientos: se trata de una forma de comunicación directa, donde prima la expresividad y el contenido, y que adopta un tono de confianza y sinceridad -frecuentemente, a modo de confesión- justificado por la cercanía del destinatario -a veces figurado, en este caso, real-. Parece estar más en la línea de la escrita por Garcilaso a Boscán que en la tradición horaciana iniciada en castellano por Hurtado de Mendoza y Boscán, tanto por su contenido como por su forma (versos endecasílabos libres en lugar de tercetos encadenados). Al tratarse de una epístola familiar, es fundamental en ella la función informativa, el dar noticias después de un silencio excesivo, el comunicar su estado físico y anímico:

Por tanto vos, mi Cosme, no toméis
admiración de ver cuán torpe y rudo,
cuán áspero, cuán bajo y cuán trocado
se os da el entendimiento en esta carta,
la cual sólo escribí por daros cuenta
de la salud que, Dios loado, tengo
más firme y más en sí que jamás tuve.

No hay una larga reflexión moral o espiritual como en la renombrada «Epístola a Arias Montano», ${ }^{12}$ aunque sí juicios de valor acerca de la vida de la corte y críticas puntuales, no generalizadas ni abstractas como es habitual en las epístolas morales de raigambre horaciana. Gracias a la localización temporal y espacial que caracteriza al género, podemos conocer el momento y lugar de escritura: Bruselas, 10 de Marzo de 1568. Aldana dice llevar once meses allí, por lo que debió de llegar en Abril de 1567, ocho meses después del furor iconoclasta y cuatro meses antes de la irrupción del duque de Alba -de quien debía de ser camarero- con su gran ejército.

La carta está marcada por una gran nostalgia de Italia, donde la vida de soldado de Aldana se enriquecía con la naturaleza, la amistad, la familia, el amor y la poesía. Esta añoranza de Italia desde Flandes era una experiencia muy común entre las tropas, ya que el sistema de reclutamiento solía ser circular: los soldados novatos eran enviados desde la península (especialmente Castilla) a Italia para que se iniciaran en la vida militar; una vez habituados a ella, eran destinados a Flandes, donde luchaban contra los franceses o contra los rebeldes holandeses; y cuando el Estado lograba el dinero suficiente eran licenciados y podían volver a España hasta que volvieran a reclamarles.

\footnotetext{
11 Aldana, op. cit., p. 280, vv. 99-105.

12 Según Rivers (1955), p. 58, en Flandes debió de conocer Aldana a Arias Montano (que se hallaba en Amberes entre 1568 y 1572 dirigiendo la segunda edición de la Biblia Políglota) y a Bernardino de Mendoza, por lo que en cierto modo su estancia pudo influir también en su evolución religiosa, del mismo modo que en Florencia los círculos neoplatónicos le habían formado filosóficamente.
} 
La vida en Italia resultaba mucho más tranquila y acomodada, ${ }^{13}$ como señala Geoffrey Parker:

[...] a partir de 1535, Italia estuvo en paz; las guarniciones españolas sólo hicieron la guerra de razzia contra los piratas de la costa berberisca [...] El servicio militar en Italia gozó por esta causa de gran aceptación entre los soldados y fue muy estimado por el gobierno; para aquellos representaba la buena vida con mujeres, vino, sueldos y botín; a éste le ofrecía la seguridad de poder continuar el dominio sobre Italia. ${ }^{14}$

Por este motivo, la moral de las tropas que llegaban a Flandes desde las guarniciones en Italia o «presidios» solía ser muy baja, así como su experiencia militar, de ahí que el príncipe de Parma, comandante del ejército en los territorios de 1578 a 1592 , creyera que «un soldado que no avia tocado el ayre de Italia era mejor en Flandes que dos de los que avían estado alla, que nunca pierden el cariño de volverse». ${ }^{15}$ Este deseo de regresar a Italia, que a veces llegó a motivar deserciones, llevó a algunos estadistas como el duque de Feria a considerar un cambio del sistema, lo que era de dudosa aplicación debido al peligro del transporte marítimo por el norte, y a la imposibilidad de atravesar Francia en tiempo de guerra. De este modo, los soldados siguieron llegando a Flandes por el llamado «Camino Español», que cruzaba Europa a través de posesiones de los Austrias o de sus aliados, y cuyo recorrido solía ser lento y dificultoso, con problemas de alojamiento y aprovisionamiento. La movilización de un número tan grande de soldados, cuya mayor fuerza era en la Edad Moderna la infantería, era muy complicada; así como su acomodo, por el temor que inspiraban los tercios en las poblaciones por sus abusos y pillajes.

Tal vez el silencio de Aldana durante tantos meses y la preocupación de la familia por la falta de noticias se expliquen por el peligro y la dureza del viaje. Sin embargo, el poeta justifica su tardanza en escribir por la falta de inspiración que padece desde que está en Flandes, y por la dificultad de evadirse de sus circunstancias y pensar en sus seres queridos. Así, Florencia y Bruselas se contraponen claramente, no sólo desde la perspectiva de soldado, sino también desde la de poeta -no hay que olvidar que para los poetas soldados Italia no sólo suponía un destino más cómodo, sino también un

13 Parece que esta situación era excesiva, puesto que historiadores de la época como Carlos Coloma atribuyeron parte de los desastres de la guerra al poco aguante de los soldados tras su vida de disfrute en Nápoles, como recoge Geoffrey Parker, El ejército de Flandes y el Camino Español. 1567-1659, Madrid, Alianza, ed. revisada y ampliada en 2006, p. 258.

${ }_{14}$ Geoffrey Parker, op. cit., p. 67. Sin embargo, no parece que la nostalgia de Aldana se debiera al vino o a las prostitutas, sino a que en Florencia gozaba de la cercanía de amigos y familiares, del ambiente intelectual, y de la presencia de alguna amada. Así lo indican las octavas de Cosme de Aldana citadas en Rivers (1955), pp. 39-40.

15 Citado por Geoffrey Parker, El ejército de Flandes y el Camino Español. 1567-1659, Madrid, Alianza Universidad, 1985, p. 262. 
ambiente cultural enriquecedor-. Una simboliza la luz, la felicidad, la inspiración, el amor; ${ }^{16}$ la otra la oscuridad, el frío, la esterilidad, la soledad:

En fin, en fin, la tenebrosa noche salió de aquel dorado y claro día, y como allá dejé la mejor parte de mí, de amor, del tiempo y de fortuna, allá quedó también, con bienes tantos, la musa. ¡Oh musa mía!, pues calla, queda, queda, quédate en paz, que aún pienso en breve darte un millón de abrazos y de besos. ${ }^{17}$

Una vez realizadas las demostraciones de afecto, las disculpas y excusas (también muy propias del género), Aldana comienza a describir su situación al servicio del duque de Alba, primero exaltando la confianza que les une y el deseo de alcanzar la fama junto al capitán general de Flandes: «Aquí me estoy con mi señor y amigo.../ gozando de mirar cómo me mira/con ojos de verdad, de amor y gracia», «oh cómo pienso, oh cómo, inmortalarme/con el nombre inmortal de este gran hombre». ${ }^{18}$ Sin embargo, a continuación parece asomar una cierta crítica y cansancio de la vida en la corte de Bruselas, enredado entre las intrigas de los consejeros del duque. El poeta parece añorar la vida militar más activa, lejos de los centros de toma de decisiones: «La vida que ora paso aquí no es otra/que trafagar en esa corte ibera», «No quiero entrar en este abismo y centro/oscuro de mentira, en esta inmensa/de torpe vanidad circunferencia/que nunca acabaría» (vv. 114-123). Esta descripción permite imaginar a Aldana como uno de los «entretenidos» u oficiales que vivían con el duque a modo de corte, dentro del sistema que tuvo que establecer ante el vacío político creado tras la renuncia de la regente Margarita de Parma. Como explica Parker, ${ }^{19}$ Alba no había llevado consigo consejeros políticos, pues su misión iba a ser tan sólo militar, y no confiaba en los nativos, por lo que no tuvo otra opción que rodearse de consejeros elegidos entre los mandos superiores españoles e italianos. Para Aldana, esta responsabilidad es el último eslabón de su carrera militar, aunque no parece que la asuma con agrado, como expresa con ironía en los vv. 123-130:

$$
\begin{aligned}
& \text {...que al fin vine a parar do no hay plus ultra } \\
& \text { pues me puedo alabar que he sido y soy } \\
& \text { paje, escolar, soldado y cortesano; }
\end{aligned}
$$

\footnotetext{
16 Este mismo lamento por la separación de su amor, que queda en Italia mientras el poeta va a Flandes, lo que causa que la amada le abandone por otro, aparece en las «Octavas a Marte», estrofa 60, mediante la alegoría de Marte y Venus: «el día que de tu Venus te partiste/te fue como partir de su memoria; contra el germano entre los belgas fuiste, / por más acumular gloria a tu gloria/y la madre de Amor, do el Arno riega/va de un sátiro vil de amores ciega», Aldana, op. cit., p. 252.

17 Idem, p. 279, vv. 91-98.

18 Idem, p. 280, vv. 106-113.

19 Geoffrey Parker (1985), pp. 145-149.
} 
no que por esto infiera alguna parte

de aviso en mi, mas por mostrar que halla

cualquiera mal aquí su extremo y cabo. ${ }^{20}$

En el siglo XVI, efectivamente, los oficiales solían ser los segundones y los hidalgos, que no tenían ni riqueza ni séquito y eran "profesionales» del ejército, pues comenzaban desde abajo e iban ascendiendo con sus servicios. El aprendizaje descrito por el segundón Aldana (paje, escolar), como señalaba un mando militar, «iba enseñando a los grandes señores que aspiran a los mayores cargos militares, cuanto conviene subir a ellos por este camino, y no querer empezar a ser generales y soldados en un mismo día». ${ }^{21}$

Tras mostrar el significado de la misión en Flandes dentro de su carrera militar, Aldana narra con amargura la dureza del clima flamenco, quizás uno de los elementos que resultaban a los soldados más difíciles de sobrellevar -los otros, el hambre y la falta de pagas, no aparecen en la epístola-. Al igual que cuando mencionaba su estancia en la corte, Aldana dice no querer extenderse en las cosas desagradables, pero dedica a las nubes, la niebla y el frío que congela su vaho dieciséis versos (131147):

Ni me quiero alargar, Cosme suave,
a describir esta región do vivo,
do en un cerco solar de un año entero,
menos tan sólo un mes, yo nunca he visto
la serena del sol cara sin nube.
Y si por suerte el velo húmido y negro
de sus ventanas abre algún resquicio
por do un rayo de luz se muestre al suelo,
en pago de merced tan transitoria
vuelve a cerrarse y con vapor más grueso
nos carga...
¿Puédese más decir sino que cuando
despido el salso humor yo de mi boca,
antes que llegue al suelo, ya en el aire,
va congelado en cuerpo espeso y duro? ${ }^{22}$

Aldana se extraña de que en tales circunstancias no haya caído enfermo, y atribuye su salud a la protección que los rezos de su madre le otorgan: «debe de ser aquella santa/...aquella casta y pura/lengua de mi piadosa engendradora». La

20 Aldana, op. cit., pp. 280-281, vv.123-130.

${ }_{21}$ Citado en Parker (1985), p. 158. Según Parker, el grado más alto al que podían llegar los hidalgos era el de «entretenidos», mientras que los segundones podrían llegar a tener puestos de mando independientes. La motivación para ir a la guerra podía ser el dinero, el prestigio o la esperanza de lograr el favor real.

${ }^{22}$ Aldana, op. cit., p. 281, vv. 131-47. 
figura materna aparece como un puente entre Dios y el hijo, pues con su bondad logra su protección: «siempre estará pidiendo al Rey eterno/el bien que yo por mí no he merecido». Y Aldana se desespera por compensar este bien: «Mas, ¿qué podré hacer, puesto que haga/cuanto al poder mortal sea más posible/que a vuestro merecer poco no sea?». La despedida de la carta, como es esperable en esta época en la que la muerte convive con el hombre, está plagada de buenos deseos de salud y protección divina, así como de muestras de afecto: «Guarde el mismo Señor vuestra persona/muy querida de mí, por muchos años/y os dé cuanto yo os quiero y merecéis», «El que en verdad os precia, ama y desea» (vv. 185-190). Toda la epístola está teñida por la sorpresa de Aldana ante el desajuste entre su estado físico y su estado mental: no comprende que estando a disgusto, en un lugar que le desagrada, con un tiempo horrible, e invadido por la melancolía, conserve buena salud. La brevedad de la carta y su escasez de noticias motivó una respuesta quejosa de Cosme, que jugando con los versos de su hermano acerca de la cortedad con la que le informa de la corte, le escribe: «mas debe ser costumbre de esa corte/acortar las razones de tal suerte/que allí acabe la carta adonde suele/empezar sin tener debido medio». ${ }^{23}$ A juzgar por la respuesta de su hermano -que permanece en Italia como soldado-, la epístola sólo ha cumplido en parte con su función principal, puesto que ha tranquilizado a la familia pero no ha satisfecho por completo su curiosidad. Quizá la parquedad del poeta a la hora de detallar su disgusto se deba a la prudencia (no sería correcto que sus superiores descubrieran sus pensamientos), pues si no, no se entiende que siendo tan difícil la comunicación -y por ello tan intermitente y espaciada- no aproveche su única respuesta en casi un año para explayarse. $\mathrm{O}$ tal vez su voluntad literaria -estilística- se imponga sobre la comunicativa, y prefiera no seguir escribiendo cuando no se siente inspirado. $\mathrm{O}$ simplemente, puede que sus obligaciones en la corte le impidieran extenderse todo lo que su hermano hubiera deseado.

No hay duda de que el problema bibliográfico ${ }^{24}$ que presenta la obra de Aldana, al haberse perdido parte de sus manuscritos y al haberse editado la otra parte tras su muerte, por iniciativa de su hermano $\operatorname{Cosme}^{25}$ (en dos volúmenes: Milán, 1549 y probablemente Bruselas 1593/95) afecta también a los poemas escritos en su etapa

${ }_{23}$ Citado por Lara Garrido en la anotación de la p. 283 de su edición de Aldana.

24 Para un resumen de la problemática, véase la introducción de Lara Garrido, pp. 106-114. También su artículo «Las ediciones de Francisco de Aldana: hipótesis sobre un problema bibliográfico», Revista de estudios extremeños, Vol. 42, № 3 (1986), pp. 541-584. Para una revisión reciente, véase I. García Aguilar, «Cosme edita a Francisco de Aldana: problemas de la edición póstuma» en Cánones críticos en la poesía de los Siglos de Oro, Madrid, Academia del Hispanismo, 2008, pp. 191-206.

25 El mismo hermano reconoce en un soneto que Aldana nunca hubiera permitido la edición de sus poesías, y que el estado desordenado y fragmentario de las mismas dificultó la presentación de las mismas para la imprenta. Véase A. Lefebvre, La poesía del capitán Aldana, Concepción, Universidad, 1953, pp. 19-22. 
flamenca, quizá en mayor medida por su participación en combates y asedios (donde pudieron desaparecer los papeles que llevaba consigo). ${ }^{26}$ A pesar de ello, las huellas de Aldana en Flandes, y de Flandes en Aldana, pueden rastrearse en otros poemas, aunque aparezcan de forma más tenue.

Por ejemplo, en los «Pocos tercetos escritos a un amigo» el poeta refleja el comienzo de la guerra abierta entre los rebeldes flamencos y las tropas de duque de Alba, cuando en abril de 1568 Luis de Nassau reunió un gran ejército y atacó en Heeiligerlee, logrando la victoria; siendo después derrotado en Jemmingen (julio 1568). Aparece el Aldana «capitán de infantería y diversas veces en Holanda gobernador de compañías así españolas como valonas y alemanas con cargo a la artillería», como se presenta ante Felipe II. ${ }^{27}$ Lara Garrido ${ }^{28}$ ha establecido la correspondencia entre los versos de Aldana y esta última batalla, acudiendo a fuentes de la época como Cabrera de Córdoba, Bernardino de Mendoza, Cornejo... y comparando las descripciones.

En esta epístola, que sigue la métrica establecida por Hurtado de Mendoza y Boscán, prima la intención moral sobre la informativa; es decir, de trata del modelo alternativo al anteriormente seguido. Aldana, ya lejos de la corte y en plena acción militar, explota el contraste entre la vida del soldado y la del cortesano, mostrando su orgullo por pertenecer a los primeros. Esto demuestra que el descontento expresado por el poeta a su hermano no era fruto de su condición de soldado sino de su circunstancia de inactividad. Aldana se describe de forma épica: «sayo de hierro acá yo estoy vistiendo, / cota de acero, arnés, yelmo luciente/que un claro espejo al sol voy pareciendo». ${ }^{29}$ La vida de su amigo, según el poeta, se caracteriza por la riqueza («oro», «seda», «púrpura»), la inmoralidad («alma vil», «andáis lascivamente», «urdiendo mil trampantojos», «manchada el alma más que el piel de armiño»), los juegos amorosos («andáis con la memoria/llena de las blanduras de Cupido», «andáis...metido todo/ en conocer la dama, o linda o fea»), la debilidad («publicando de vos llorosa historia») y una coquetería más propia de las damas («tierno celo», «flores de azahar», «los pulsos refrescando, ojos y frente», «todo compuesto, andáis ventaneando»). Por el contrario, el soldado aparece sucio, pero de «honroso sudor» $y$ «sangre enemiga»; tiene objetivos elevados («puestos los ojos en muerte dar al que tener se gloria/del ibero valor ricos despojos», «lleno de gana que Ludovico al fin quede vencido») y una

\footnotetext{
${ }^{26}$ Así lo señala Cosme de Aldana en cuanto a las «trece Octavas a la Creación del Mundo, de 900 que eran y se le perdieron en Flandes con muchas obras suyas, entre los enemigos», citado por A. Lefebvre, op. cit., p. 22.

${ }^{27}$ Citado por Lara Garrido -del memorial de Aldana a Felipe II- en la p. 25 de la introducción a su edición.

${ }^{28}$ Lara Garrido, edición citada, pp. 24-26.

29 Aldana, op. cit., p. 289, vv. 4-6. Para las citas del mismo poema, véase p. 290.
} 
vida llena de incomodidades («sobre un jinete acá saltando/el andén, el barranco, el foso, el lodo»). La presentación que hace es de nuevo épica, aunque refleje hechos históricos: «de sangre enemiga el brazo tiño/cuando con más furor muerte dispara» parece reflejar el ataque con arcabuces; los despojos del ibero valor aluden -según Lara Garrido- a la ejecución de los prisioneros de Heeiligerlee; «yo voy acá de furia combatido/de aspereza y desdén», «al cercano enemigo amenazando», «yo reconozco el sitio y la trinchea/deste profano a Dios, vil enemigo» muestran las distintas fases del combate (exploración del campo enemigo a caballo, ataque...). La mentalidad militar aparece perfectamente descrita, ya que el enemigo se ve como una masa informe que representa todo lo malo (profana la religión, es vil...); y la lucha como algo violento y heroico al mismo tiempo, que hace al soldado sentirse poderoso, siempre que se acostumbre a las dantescas imágenes que le rodean («sin que la muerte al ojo estorbo sea»).

Aunque el poema no explicita lo que esta masacre significó (según los testimonios históricos, en menos de dos horas los cuatrocientos españoles degollaron ocho mil hombres), sí el ambiente de exaltación y arrojo, que sin duda marcó al poeta soldado, ya que emplea su primera faceta para elevar la segunda (el poeta convierte al soldado en héroe). El tono triunfante de la epístola parece indicar que se escribió tras la victoria, pues, según Parker, «desbarató toda la campaña de la oposición contra Alba», ${ }^{30}$ porque los orangistas perdieron el apoyo de Inglaterra, los príncipes alemanes y hasta de los habitantes de los Países Bajos. Tras Jemmingen, el duque de Alba consideró que había cumplido su misión de abrir camino a la visita del rey, pues la rebelión parecía controlada. Pero éste, en plena crisis sucesoria por la muerte de su heredero Carlos y su esposa, no podía exponerse a ningún peligro. Así que el duque tuvo que permanecer en Flandes con poderes absolutos, como refleja Aldana en las octavas que le dirige ${ }^{31}$ (también a modo de epístola) aunque elogiándole como estandarte de la luz frente a la herejía:

Ésta de cuya luz, cuyo sujeto, de cuya autoridad todo se enfrena, ...hará que cuanto ve le sea sujeto.

Claro está que la actuación del duque, tanto en la represión religiosa y política como en la reorganización impositiva necesaria para mantener al ejército, era vista de modo opuesto al del capitán por la población flamenca. Sirva de ejemplo el panfleto repartido por las calles de Gante en marzo de 1572, transformación paródica del «Padrenuestro»:

30 G. Parker, España y la rebelión de Flandes, Madrid, Nerea, 1989, p. 109.

31 Aldana, op. cit., p. 291-295. 
Padre infernal que estás en Bruselas, maldito sea tu nombre en infiernos y tierras, consúmase tu reino, que ya ha durado en exceso (...)

Ninguna deuda tu perdón alcanza;

El pan que te nutre es la venganza (...)

Que este demonio parta ligero.

Y con él, su Consejo, falso y sanguinario, que del crimen y el robo hacen su arte diario.

Y a todos sus hispánicos perros marciales devuélvelos a los abismos infernales. Amén. ${ }^{32}$

El año en que se difundió esta sátira, estalló la segunda rebelión en los Países Bajos; y Aldana, que en 1571 había vuelto a Madrid con recomendaciones del duque de Alba, pero se había enrolado en la segunda campaña de Juan de Austria contra los turcos, regresó a Flandes para auxiliar a las tropas que sitiaban Haarlem. El sitio duró desde diciembre de 1572 a julio de 1573, y terminó cuando la ciudad se rindió ante la promesa de Alba de no maltratar a nadie, promesa que incumplió, pues dos mil personas fueron ejecutadas. ${ }^{33}$ Esto tuvo una grave consecuencia: a partir de entonces ninguna ciudad holandesa se rindió sin ofrecer resistencia, como muestran las heridas recibidas por Aldana -parece que ascendido a general de la artillería- en el sitio de Alkmaar (1573), que fracasó. Encontramos una descripción burlesca de su convalecencia de dichas heridas en el "Diálogo entre cabeza y pie», ${ }^{34}$ donde ambas partes discuten cuál ha sido la culpable del mosquetazo recibido. En las quejas del pie a la cabeza parece subyacer una crítica a sus superiores, verdaderos responsables de lo sucedido:

$$
\begin{aligned}
& \text { PIE: Nosotros obedeciendo } \\
& \text { lo que ellos mandan en todo, } \\
& \text { por el agua y por el lodo } \\
& \text { pasando, andando y viniendo } \\
& \text { sin descansar de algún modo. }
\end{aligned}
$$

Sin duda, la visión de Aldana de su vida de soldado ya no es tan épica como en los tercetos escritos a un amigo. El propio duque de Alba describía a Felipe II las condiciones del sitio de Alkmaar con crudeza:

El tiempo el más terrible que se ha visto jamás, que en todo el mes pasado y parte déste no ha hecho otra cosa que llover, de manera que ya en todo el campo no

\footnotetext{
32 Fragmento del «Paternóster de Gante», citado por G. Parker (1989), p. 126.

33 G. Parker (1989), p. 158.

34 Aldana, op. cit., p. 385.
} 
se podía andar sino con el agua hasta la rodilla, entrando los soldados a hazer la guardia descalços y el artillería casi anegada $[\ldots]^{35}$

La dureza de esta segunda etapa de la guerra, agravada por el estallido de motines entre los tercios (que intentaban así lograr que les pagaran), multiplicó los deseos del soldado de licenciarse.

Sin embargo, su estancia se alargó, debido a la sustitución de Alba por Requesens -que conllevó su degradación a capitán-, y al recrudecimiento de los motines. El nuevo gobernador le encargó interceder ante las tropas de Leiden para que se sosegaran,

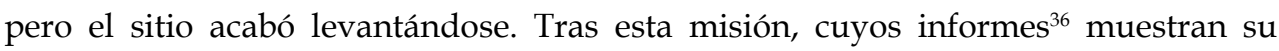
desaprobación de los motines y su preocupación por la situación, Aldana logró volver a Madrid, deseando abandonar la vida militar: «el hábito de mi soldadesca ya se rompió y me será fuerza procurar otro de más seguridad». ${ }^{37}$ Sin embargo, en recompensa por sus servicios no obtuvo ningún descanso, sino el encargo, en 1576, de guardar la fortaleza de San Sebastián; y en 1577, de viajar al norte de África como espía, pues Felipe II quería más información para decidir si ayudaba a su sobrino Sebastián de Portugal en la conquista que planeaba. La carrera diplomática de Aldana llegó a su cumbre cuando el rey le encargó convencer a Sebastián de la imposibilidad de la empresa, aunque durante la entrevista, el poeta cambió de parecer y en su memorial acabó recomendando al rey que apoyara a su sobrino por la importancia de la «cruzada». Mientras Aldana creía ganado su retiro tras esta misión, don Sebastián insistía a Felipe II en que el poeta le acompañara en su campaña, hasta que finalmente el rey accedió en junio de 1578. Tras alcanzar al ejército del rey portugués -a quien tenía que entregar una carta del duque de Alba con la estrategia a seguir- y ser nombrado «superintendente del ejército» (culmen de su carrera militar), Aldana intentó convencer a don Sebastián para que abandonara el plan, consciente del peligro que corrían, pero cuando vio que era demasiado tarde para retroceder, se unió al ataque, y murió con él y con la mayor parte de la nobleza portuguesa, a los cuarenta y un años. En definitiva, Aldana tuvo una muerte heroica, acorde con la imagen que proyectaba de sí mismo en los «tercetos a un amigo», pero muy distinta de la que parecía anhelar cuando le escribía a Felipe II, ya hastiado de la vida militar tras la segunda experiencia flamenca, ${ }^{38}$ recordándole su lealtad y sacrificio:

\footnotetext{
35 Citado por Rivers (1955), p. 68. Se trata de una carta cifrada con la fecha 23 de octubre de 1573.

36 Véase la carta a Requesens a 23 de febrero de 1576, reproducida por Rivers (1955), pp. 76-78, donde después de aconsejarle lo que debería hacer, suaviza su posición humillándose: «Soy un gusano».

37 Citado por Lara Garrido en la introducción a su edición, pp. 30-31.

38 M. J. Martínez López, «La primera redacción de las Octavas dirigidas a Felipe II de Francisco de Aldana y su inédita dedicatoria en prosa», Criticón, $\mathrm{n}^{\circ} 70$ (1997), pp. 31-70, propone que la redacción de las octavas tuvo que ser anterior a la fecha antes establecida (finales de 1577-1578) por la fecha de la
} 
también mis canas, mis servicios, mi ronca voz movida a tus loores, mis destrozados miembros, mi quebranto, mis cuidadosas ansias, mis dolores $(. .$. $\mathrm{mi}$ reprimir de muerte los horrores, mis huesos, y mi sangre, y cuanto digo, sí que también podrán algo contigo. ${ }^{39}$

Es en estas mismas «Octavas al rey don Felipe» donde encontramos la rememoración que, ya lejos de Flandes, hace Aldana de sus años allí, dejando patente una vez más el impacto que el conflicto le causó, y la sangre que derramó en él, mezclándose la humedad de este humor con la de la tierra norteña:

\author{
Mas dudo, jay triste!, a Belgia, cuyo suelo \\ quiero y puedo afirmar no vanamente \\ haber de sangre, yo, rebelde al cielo, \\ teñido alguna vez, con ira ardiente; \\ otro después quedó mi frágil velo \\ tendido en él con húmida corriente \\ del mismo humor, ${ }^{40}$ según o mala o buena \\ voluntad del destino al hombre ordena. ${ }^{41}$
}

\title{
3. Andrés Rey de Artieda: de la esperanza a la sátira.
}

Andrés Rey de Artieda tuvo una vida militar tan intensa como la de Aldana, pero por la diferencia cronológica sus caminos no coincidieron ni en Italia ni en Flandes. Según los datos ofrecidos por Antonio Vilanova, ${ }^{42}$ nació en Valencia en 1549, hijo de

dedicatoria a Felipe II, en octubre de 1576, es decir, ocho meses después de abandonar Flandes y llegar a la corte para esperar alguna recompensa a sus servicios. Propone también que en septiembre de 1577 Aldana revisara el texto e introdujera referencias a Sebastián de Portugal, y acentuara la reivindicación de sus servicios en Flandes, versión transmitida por los impresos.

39 Aldana, op. cit., p. 422, vv. 713-720. En el memorial en prosa escrito en Septiembre de 1577 al rey, le pide servirle los últimos años de su vida como alcaide de San Sebastián.

40 Este pasaje, de difícil interpretación, podría significar que Aldana se considera a sí mismo de temperamento sanguíneo, es decir, según la teoría galénica, dominado por el humor de la sangre, y con una tendencia al entusiasmo y a la excitación. Esto se correspondería con su expresión «con ira ardiente» e implicaría una identificación de su temperamento con la humedad de Flandes. Aldana, op. cit., p. 231, emplea esta misma imagen en las «Octavas sobre el juicio final»: «Por las venas de aquél secas y heladas/baja caliente humor de sangre pura», y en muchas más ocasiones emplea «humor» como sinónimo de «agua», v.g. «de todo humor vaso es Neptuno» en «Parto de la Virgen» (p. 326) o « sentí de entrambos ojos/caliente humor buscar salida al aire/de estos mis ojos, nunca a tal usados» en la «Epístola a Galanio» (p. 361-362). Este segundo significado parece predominar también en otros poetas del XVI.

${ }^{41}$ Aldana, op. cit., p. 416, vv. 553- 560. Esta estrofa es precisamente uno de los añadidos que, según M. J. Martínez López, op. cit., p. 37-38, Aldana pudo realizar en una redacción posterior, con la clara intención de conmover al rey con su reivindicación de haber derramado sangre por él, y conseguir con ello alguna merced.

42 A. Vilanova, Introducción a Discursos, epístolas y epigramas de Artemidoro, Barcelona, Selecciones Bi- 
un notario. Como Aldana, recibió una buena formación humanística, alcanzando el título de bachiller en Artes en 1563 y en Leyes en 1574. Desde muy joven cultivó la poesía, y fue elogiado por Gil Polo en su Diana enamorada. Según Teresa Ferrer, ${ }^{43}$ llegó a ejercer como abogado, pero pronto optó por la profesión de soldado, participando en la expedición de socorro de la isla de Chipre y en la batalla de Lepanto (1571), por lo que se le incluye en la «generación de Lepanto», con Cervantes y Virués. Además, como capitán de infantería, sirvió treinta años en Flandes e Italia, al mismo tiempo que participaba en la Academia poética de los Nocturnos, y publicaba algunas de sus obras: Los amantes (Valencia, 1581), Octavas a la venida del rey don Felipe (1586)... De vuelta en España vivió en Zaragoza junto al Duque de Alburquerque, virrey del Reino de Aragón, donde se editaron sus Discursos, epístolas y epigramas de Artemidoro ${ }^{44}$ (Zaragoza, 1605).

La mención más importante a la estancia en Flandes de este poeta soldado aparece en la segunda parte de este poemario, en la «Carta a un amigo dándole cuenta de las cosas de Flandes», ${ }^{45}$ escrita en 1588, en el campamento de los tercios organizado entre Ypres y Dixmuide a la espera de la Gran Armada. La epístola está escrita en tercetos encadenados, en la tradición de Hurtado de Mendoza y de Boscán, aunque en ella predomina la función de la carta informativa (en la línea de Garcilaso) más que la intención moral: «quiero pintarte algunas aventuras». En ella relata su vida en la corte de Bruselas y después el ambiente del campamento, en un momento del conflicto ya internacional muy distinto al que vivió Aldana.

Tras las sucesivas victorias del duque de Parma, Alejandro Farnesio, la situación era más esperanzadora, pero para acabar con la ayuda de Inglaterra a los rebeldes holandeses, el rey y sus consejeros llevaban años planeando una invasión. El general de Flandes tuvo parte en dichos planes, sugiriendo que sus tropas embarcaran en unas barcazas escoltadas por buques de guerra para encontrarse con la Armada y atacar juntos Inglaterra. Sin embargo, a medida que pasaba el tiempo la empresa se volvía más peligrosa, pues los holandeses, como los ingleses, estaban al tanto de las intenciones de Felipe II y se proponían desbaratarlas, gracias a sus mejores barcos y a

bliófilas, 1955.

43 T. Ferrer, Teatro clásico en Valencia I, Madrid, Biblioteca Castro, 1997, p. 15.

44 Para el análisis del contenido de esta obra, véase I. Osuna, «Las epístolas de Artemidoro (Andrés Rey de Artieda)» en Grupo P.A.S.O., La epístola. Encuentros internacionales sobre poesía del Siglo de Oro, Sevilla, Universidad, 2000, pp. 234-237.

45 A. Rey de Artieda, Discursos, epístolas y epigramas de Artemidoro, Barcelona, Selecciones Bibliófilas, 1955, pp. 130-137. I. Osuna, op.cit., p. 239, recoge que en la versión de la Academia de los Nocturnos aparece como destinataria «Leonarda» y en una ocasión se titula «sátira», lo que encajaría en parte con la visión crítica de Rey de Artieda, y se explicaría por la cercanía de la epístola a la sátira debido a su raigambre horaciana, y quizá a la intermediación de Ariosto, a quien Artieda menciona como modelo en su dedicatoria. 
su conocimiento de los mares del Norte. ${ }^{46}$ A pesar de las crecientes dudas de Farnesio respecto a la viabilidad de su misión, el ambiente entre sus hombres parece tranquilo y optimista, según nos cuenta Rey de Artieda.

Una cierta crítica está presente en la comparación entre la vida de la corte en Madrid y la de Bruselas, con la que comienza la epístola. Mientras Aldana criticaba la corte flamenca, el valenciano tiene una visión más positiva, pues la asocia con el ánimo y el valor, con la valentía y el aguante de soldados y capitanes, con el control de los sentimientos y las pasiones; frente a la ceremonia, la presunción y los frívolos duelos de Madrid. En realidad, los primeros tercetos se asemejan a aquellos en los que Aldana comparaba la vida del soldado con la del cortesano, aunque en este caso no hay un ataque directo al amigo sino un planteamiento más abstracto. La consideración de la vida militar como freno a la pasión amorosa es juzgada de forma ambigua. Al principio de la epístola hay una insistencia en la necesidad de ocultar los sentimientos y controlarlos, y de evitar conflictos con los demás soldados: «Son aquí los amores niñerías/y aunque penetren corazón y entrañas/hémoslas de mostrar tibias y frías», «Si en un cabello a tu contrario dañas/por ocasión de damas o mugeres/despintas el valor de tus hazañas», «Y assí, si conservar la fiesta quieres/has de callar como incapaz y rudo/en tanto que se dan a sus plazeres/Este dolor tan áspero y agudo/con una falsa risa disimulas/o sino, con mostrarte sordo y mudo» (vv. 10-21). No es que la vida militar endurezca al soldado y le haga insensible al amor o a los celos, sino que en una situación tan extrema como es la guerra, la unión entre los compañeros ha de primar sobre los ajustes de cuentas y rivalidades. Después, le relata a su amigo el sufrimiento amoroso que le causó una misteriosa peregrina ${ }^{47}$ que llegó a la corte, «de la escuela de Circe y de Medea», que embaucó a todo el mundo («Aunque los ojos interiores abras/ternás las de su casa por ovejas/siendo rebaño indómito de cabras/Pues si está sobre sí y arquea las cejas/creerás que te cuenta el Evangelio/contándote patrañas y consejas») y le enloqueció con sus encantos («Ganó mi libertad por los oydos ${ }^{48} /$ los ojos resistiéronle un poquito/pero quedaron presos y vencidos»), hasta que Dios le ayudó («desató los candados y cerrojos/y me mostró la cárcel de mi vida»). Espantado

\footnotetext{
46 Véase J. C. Losada, Los generales de Flandes. Alejandro Farnesio y Ambrosio de Spínola, Madrid, La Esfera de los libros, 2007.

47 Este episodio, según I. Osuna, op. cit., p. 246, aparece suavizado en la versión de la Academia de los Nocturnos en la que Leonarda aparece como destinataria (hecho que motiva otros cambios para adaptar la epístola), y se menciona su identidad, Faustina de Mendoza.

48 Este enamoramiento a través de los oídos, no tan común en la poesía renacentista como el neoplatónico enamoramiento a través de los ojos, se explica por las habilidades artísticas de la mujer, descrita en el encabezamiento de otra epístola dirigida a ella como "música y poeta insigne". Esta caracterización de la amada como artista, y la insistencia no sólo en sus atributos físicos sino también en sus cualidades como poeta tampoco es muy común, aunque encontramos otros casos como el de la Marfira de la poesía de Ramírez Pagán, estudiada por Nieves Baranda (véase bibliografía).
} 
por la maldad que descubre («Quién duda que con todo el cuerpo sude/quien viere que una perra que regala/ en una sierpe se transforma y mude?»), decide salir de la corte y dirigirse al campamento. Esta vez, la milicia no se refleja como represión, sino como una cura de amor: «Y como el son armígero despide/las vanas sombras del amor lascivo/y al ocio mugeril el passo impide/troqué el amor en pensamiento altivo/y a Marte hallé en campaña tocando arma/con el qual sabes bien que a ratos privo». A continuación, Rey de Artieda ensalza a su superior, el duque de Parma -tal y como Aldana hacía con el duque de Alba-, «que contra Elisabeth de Inglaterra/con invicto valor se apresta y arma», aunque se ahorra los detalles del plan de invasión pues los da por conocidos.

La visión que el poeta ofrece sobre Flandes es más positiva que la de Aldana, pues aunque coincide en lamentar el clima norteño ( «dos o tres meses que he vivido ascuras»), elogia la «fertilidad y assiento de la tierra» y «su grandeza y hermosura estraña». Quizá ayudara el hecho de que las tropas estaban concentradas pero a la espera, pues desde agosto de 1587 las operaciones se habían interrumpido. ${ }^{49}$ Rey de Artieda debió de ser uno de los pocos valencianos en Flandes, pues los mandos militares desconfiaban de ellos por la gran presencia de moriscos en Valencia. En total se reunieron unos treinta y dos mil hombres, según el poeta «lo mejor de España», que deberían partir de Dunquerque -puerto inadecuado pero cercano a las bocas del Támesis- en unas trescientas embarcaciones.

La epístola nos muestra cómo era el ejército y cómo vivían los soldados. Describe la «cola del ejército»: los vivanderos (que suministraban víveres, dinero o crédito), mozos, prostitutas... que les acompañaban en gran número para atender sus necesidades. Quizá por las ingentes cantidades de dinero que se destinaron a la operación, hay comida y bebida abundante, y alegría generalizada, que contrasta con otros momentos de descontento del ejército, en los periodos de motines continuos ${ }^{50}$ de 1573-1576 y 1589-1597. Rey de Artieda enumera las actividades que entretienen a los hombres, entre «la grita y la barahúnda»: unos luchan, otros juegan a las barras, a las carreras, a las cartas... otros se construyen chozas (pues el alojamiento se improvisaba), o tocan la guitarra, o se divierten con las prostitutas. El poeta se detiene en estas «señoras que se dan al vicio», que «con sus arandelas y sus rizos/ de nuestro prolongado alojamiento/ocupan muchos tálamos pagizos», aunque parece no dedicarse a disfrutar en su compañía por haber escarmentado tras sus desamores con la «peregrina» («con ellas ni me tiro ni me cuento/después que el mal passado me acobarda»). Al final de la epístola, resulta sorprendente su alegría respecto a la paga

\footnotetext{
49 Véase Losada, op. cit., pp. 188-190.

50 Véase Parker (1985), p. 233.
} 
que recibe («contento con mi paga y estipendio»), dada la frecuencia con la que los problemas financieros del Imperio causaban atrasos de años, aunque es posible que para mantener alta la moral de los «invasores de Inglaterra» se les pagara, por una vez, puntualmente. Rey de Artieda compara su vida en el campamento con la que llevaba en la corte, exaltando la vida militar como solución a los males del corazón, pues cree que saca lo mejor del hombre:

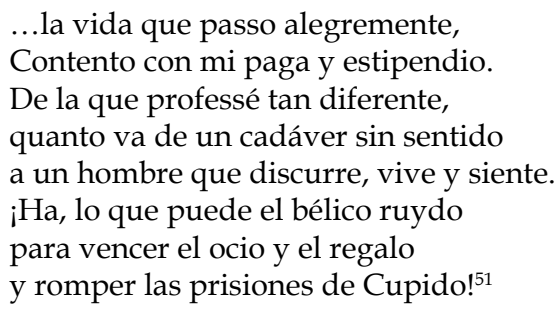

Esta visión positiva de la vida militar se refuerza por la impaciencia con que Rey de Artieda espera que la Gran Armada del Duque de Medina Sidonia se acerque a las costas para reunirse y atravesar el canal: «Por horas esperamos con la armada/al desseado Duque de Medina/para poder echar mano a la espada». Como es habitual, el poeta confía en la protección divina, puesto que se trata de un enfrentamiento contra los herejes:

$$
\begin{aligned}
& \text { Guíe la Magestad única y trina } \\
& \text { nuestros buenos deseos y destruya } \\
& \text { nación que templos y aras arruyna. } \\
& \text { Justo pedimos, causa propia es suya... } \\
& \text { Quiera Dios que nos des la norabuena } \\
& \text { del buen sucesso que esperamos luego } \\
& \text { contra la successora de Bolena. }{ }^{52}
\end{aligned}
$$

Como es bien sabido, esa «enhorabuena» que Artieda esperaba nunca llegó, pues las tropas de Flandes no llegaron a embarcar: la Armada que esperaban fue dispersada y destruida por los ingleses y holandeses, mientras otras flotillas bloqueaban los puertos flamencos. Así pues, mientras Aldana había sido testigo de la primera gran victoria contra los rebeldes, Artieda se ve afectado por uno de los mayores desastres de la guerra, según Parker «un hito trascendental en la rebelión neerlandesa», pues «debilitó decisivamente el prestigio de Felipe II y puso fin a la impresionante serie de victorias de Parma». ${ }^{53}$ Tras esta derrota, Parma llevó a sus tropas al asedio de Bergenop-Zoom, que fracasó, así como las sucesivas campañas, paralizadas por los continuos motines que estallaban. Cuando los rebeldes confiaban en sus posibilidades, comenzó

\footnotetext{
51 Rey de Artieda, op. cit., p. 136.

52 Rey de Artieda, op. cit., p. 137.

53 Parker, (1989), p. 216.
} 
una nueva guerra civil entre los católicos y los protestantes franceses, en la que el ejército español tuvo que participar.

A juzgar por el contenido de otros poemas, Artieda siguió en Flandes al menos hasta 1591. Esta región aparece en otros poemas de Rey de Artieda, así como el retrato de la vida militar, de los motines, de los abusos de los capitanes... más satírico que heroico. Por ejemplo, en la «Carta a Leonarda, música y poeta insigne», 54 cuya destinataria es la misma «Leonarda» de la que decía haberse olvidado en la epístola a su amigo antes analizada, y a quien escribe desde Brujas, también a la espera de la Gran Armada. Una vez más, el poeta relaciona amor y guerra, pues dice huir del sufrimiento amoroso volviendo al servicio: «Mi desventura y pensamientos grandes/después que de Valencia te partiste/me hizieron otra vez venir a Flandes» (vv. 4-6). Rey de Artieda confía en la pronta victoria y en la clemencia de su rey para poder licenciarse y volver a Valencia: «Pero, con todo, pienso verte luego/que la potencia de Philippo es tanta/que nos promete universal sosiego. /Según su armada y su poder espanta/ya veo al General Inglés vencido/y vitoriosa nuestra Iglesia Santa». ${ }^{55}$

Un testimonio importantísimo es el de la «Carta a don Francés de Pinos», ${ }^{56}$ pues en ella se refleja la etapa de los motines, $^{57}$ de cuyos primeros problemas Aldana había sido testigo. Rey de Artieda explica a su amigo el descontento de los soldados en Flandes, y trata de justificar que sus quejas por no recibir las pagas no son una muestra de deslealtad al rey o de cobardía. ${ }^{58} \mathrm{El}$ poeta está convencido de que las penurias que sufre un soldado son insuperables:

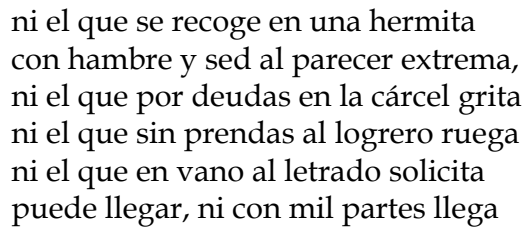

54 Rey de Artieda, op. cit., pp. 123-130.

55 Rey de Artieda, op. cit, p. 130.

56 Idem, pp. 168-174.

57 Según J. M. Alegre Peyrón, «El ejército, gran protagonista de la política exterior de los Austrias españoles» en La espada y la pluma, Luca, Mauro Varoni, 2000, p. 21, «entre 1572 y 1607 se produjeron en el ejército de Flandes más de 45 motines [...] Esta reiteración de la desobediencia organizada, sin paralelo en otros ejércitos, era una protesta colectiva, una especia de huelga con el fin de persuadir al estado a tratar a sus empleados más honestamente».

58 Parecida justificación de los motines pone Lope de Vega en boca del Duque de Parma en su obra «El asalto de Mastrique»: «Tengo temor que amotinarse quieren, / porque la sed y el hambre los aflige, /y ha mucho tiempo que la paga esperan». Citado por D. García Hernán, La cultura de la guerra y el teatro del Siglo de Oro, Madrid, Sílex, 2006, p. 151. 
El hambre y la carencia de un hogar son lo más duro de la milicia: «El soldado, so pena de la vida/la suya guarda, mil días no come/ni se le sabe casa conocida» (vv. 22-24). Rey de Artieda muestra aquí la otra cara de la moneda, las épocas de hambre, frío, deudas... que eran las más frecuentes. También confiesa que sólo la costumbre le permite aguantar: «El año que novicio fuy, espantóme/quíseme retirar, pero no ay cosa/que el tiempo y la costumbre no la dome» (vv. 25-27). Estas penalidades, sumadas a los peligros que corren los soldados, justifican las quejas: «como no intervenga junta o liga/no has de pensar que sea motín abierto/comunicar con otro su fatiga». Es decir, para Artieda su crítica directa no supone una deslealtad. Para argumentar su opinión, introduce una anécdota vivida en Diest, probablemente en los tiempos del primer motín (1590), una época de hambre («Estando yo una noche muy despierto/porque, tras que comíamos a talla/el crédito corriente estaba muerto»). Los protagonistas son dos soldados de ronda «cuya hambre y desnudez la historia calla». Éstos se lamentan por sus ropajes (el gobierno casi nunca los suministraba, y muchas veces iban cubiertos de harapos); por el comportamiento de su capitán (solían tener un gran poder, del que muchas veces abusaban, especialmente cuando eran los encargados de repartir los sueldos)... hasta proponer abandonar el ejército:

Vámonos, pues, los dos de camarada
ya que la dulce patria nos combida
y el trato desta tierra nos enfada.
Siga la gente mísera y perdida
digo, los capitanes y soldados
éste infelice género de vida. ${ }^{60}$

La deserción, junto con los motines, aumentó en los periodos en los que el Estado no lograba dinero para pagar a las tropas, y fue otro de los elementos de desgaste que impidieron la victoria. Los dos soldados del diálogo critican a continuación la inmoralidad de los capitanes, que se dedican a la buena vida con las prostitutas: «A los más bravos capitanes diles/que las que ocupan sus sobervias tiendas/son mugeres infames y serviles», «Silleta, palafrén, litera y coche/tanto aparato y tráfago de dia/tanto festín y máscara de noche». La epístola termina con la firme defensa de los soldados y de sus motivos, pues a pesar de sus críticas y sus deseos de volver a España, una vez recibieron sus pagas, se comportaron como héroes: «con solo sus espadas y sus dagas/passando a nado un fosso, hizieron cosas/que plegue a Dios que en ocasión las hagas», y acabaron siendo capitanes en Flandes y en Italia. La alusión a

${ }_{59}$ Rey de Artieda, op. cit., p. 168, vv. 11-18.

60 Rey de Artieda, op. cit., p. 171. 
la heroicidad de los soldados parece evocar la suya propia, pues cruzó el río Ems en pleno invierno con un cuchillo en la boca y bajo fuego enemigo.

En la «Carta a doña Juana, armígera en extremo» ${ }^{61}$ aparece de nuevo la interrupción de su descanso por una nueva misión militar, hacia 1598, con Italia como destino:
Libre ya de cuidados militares [...]
Gozava de este ocio y quietud bendita
quando el Rey me mandó con una carta
firmada en hora marcial y escrita
que a Çaragoça por momentos parta
y arbole en nombre suyo una bandera
que en su real servicio fue la quarta. ${ }^{62}$

En estos versos vemos uno de los sistemas de reclutamiento de la época, la comisión, por la cual un capitán iba recorriendo pueblos y ciudades -en este caso, del reino de Aragón, por ser el destino Italia- hasta formar una compañía. ${ }^{63}$ Rey de Artieda menciona dicho proceso: «Cobré con el dominio y poder alas/y en un instante recogí en mis redes/gentes sin elección, buenas y malas». ${ }^{64}$ Una vez más, su anhelo de una vida sosegada y su profesión -quizá vocación- militar entran en conflicto, ${ }^{65}$ pero intenta ver lo positivo de su movilización:
[...] aunque en paz y quietud quisiera
prolongar el vivir, me fue forçado
bolver al siglo y profesión primera.
Y como no envejece el que es soldado
adornado de plumas y de galas
el paño honesto convertí en brocado. ${ }^{66}$

Sin embargo, en muchos versos aparece el hartazgo de la milicia, que le aleja de sus amores: «vengo a perder, señora, la paciencia/quando me veo en lo peor de

${ }_{61}$ Rey de Artieda, op. cit., p. 137-144.

${ }^{62}$ Idem, p. 137-138, v. 5 y vv. 13-18.

63 Parker (1985), p. 73.

${ }^{64}$ Esto coincide con Parker (2006), p. 67: «el servicio en Italia era muy popular: las levas para Italia siempre tenían éxito». Los motivos del éxito, según B. Bennassar, La España del Siglo de Oro, Barcelona, Crítica, 1983, p. 315-316, eran la relativa seguridad alimentaria, el poder adquisitivo pese a la devaluación de los salarios, la ausencia de gastos de transporte, alojamiento, la exención de impuestos y la posibilidad de enriquecerse con los botines.

65 Compárese esta contradicción entre el deseo de quedarse y la realidad de la movilización, con el lamento de Cristóbal de Virués al no poder unirse a una compañía: «Fiero mal que estorbaste mi alto intento, /aunque mortal angustia el cuerpo siente, / más sin comparación que su acidente/velles partir y yo quedarme siento», citado por J. Lara Garrido, «"Palma de Marte" y "Lauro de Apolo": la poesía del "oficio militar" en Francisco de Aldana y Cristóbal de Virués» en La espada y la pluma, Luca, Mauro Varoni, 2000, pp. 308-309.

${ }^{66}$ Rey de Artieda, op. cit., p. 138, vv.19-24. 
Italia $^{67}$ /ageno de tu angélica presencia». Amor y soldadesca están tan entrelazados, que Rey de Artieda explica sus sentimientos con una metáfora militar: «eres tú como el azero/que el tosco ymán con su virtud atrae». Por último, el poeta trata de infundir esperanzas en su amada, y de justificar que no es soldado para ganar fama o dinero:

Y no quiero que pienses o que entiendas
que he de vivir aquí siglos enteros
ganando honras y adquiriendo haziendas.
Dexa que ogaño prueve mis azeros
que en fe de agradecido te prometo
de no estar en Italia dos eneros. ${ }^{6}$

Aparece también la preocupación por la deshonra que al soldado pueda acaecerle según el comportamiento de la amada en su ausencia: «En este medio, guárdame el respecto/que deves al amor que te publico».

En la tercera parte de su obra, los sonetos o epigramas, hay alusiones burlescas a la vida militar: a la camaradería, definida por Parker como cinco o seis compañeros que «vivían juntos y compartían beneficios, pertenencias, peligros»; ${ }^{69}$ a las frustradas aspiraciones de los soldados ( A los discursos vanos» ${ }^{70}$ presenta a un centinela soñando con ser alférez, general, príncipe y rey); a la solidaridad ( $\mathrm{A}$ un soldado camarada del capitán Antonio Vázquez»: ${ }^{71}$ «es un soldado muy bizarro/si marcha al campo, guía bien un carro/si hay huéspedes/visita la cocina»... ). Artieda recoge también la creciente mala fama del soldado, antes visto como un héroe, en «Al estado presente de la soldadesca»: ${ }^{72}$ «-¿Sabéis el misterio/porqué, de algunos años a esta parte, nuestra arte militar (si acaso es arte)/se tiene por infamia y vituperio? -Ser nuestra profesión común a todos/y atender cada qual a su provecho». Efectivamente, la imagen del soldado cada vez se iba deteriorando más y más, pasando de asociarse con la virtud y de ser la profesión mejor considerada tras la religiosa, a identificarse con la violencia indiscriminada. ${ }^{73}$ Artieda cree que se debe al fácil acceso a la misma por parte de las capas más pobres de la población, que buscan ante todo enriquecerse, no cumplir con

\footnotetext{
67 Llama la atención la referencia negativa a Italia por contrastar con la visión habitualmente positiva que aparece en los testimonios de los soldados y en Aldana, en éste caso debido a que el poeta soldado se había separado de su amada, que dejaba en España, frente a los que encontraban el amor en Italia y lo perdían al ser destinados a Flandes.

68 Rey de Artieda, op. cit., p. 144.

69 Parker (1985), p. 222.

70 Rey de Artieda (1605), f. 104.

71 Idem, f. $106 \mathrm{v}$.

72 Idem, f. 110.

73 Véase D. García Hernán, La cultura de la guerra y el teatro del Siglo de Oro, Madrid, Sílex, 2006.
} 
su deber. ${ }^{74}$ Esta visión oscura del soldado aparece también en el primer poema de la edición de Rey de Artieda, las octavas «Discurso sobre la vanidad y aflicción del mundo. A don Antonio de Cardona», donde escoge como blanco de sus críticas tanto al cortesano como al militar (incluido el poeta soldado), que describe así:

Tiene esta gente miserable y pobre del sueldo antiguo nombre de soldados, pero otros creen, que el apellido cobre del Sol que los abriga y de los dados [...] Mas tóquese la caja y verás luego La gentecilla ilustre que se aplica, a la furiosa máquina de fuego o a la soberbia y ambiciosa pica [...] si hombre hallares bueno, no me digas que más ajes tendrá que las ortigas [...] Recogida la gente, hechas las listas, tú que eres capitán luego decretas que estos hayan de ser caporalistas, y estos otros paraninfos y plumetas: Restirate con dos o tres sofistas, músicos, bailarines y poetas, que con su liviandad y poco seso muestra señor entretenerte el peso. ${ }^{75}$

\section{IMÁGENES DE LA VIDA MILITAR}

La visión heroica del soldado, tan presente en la literatura del Siglo de Oro, acaba siendo superada por la visión satírica a medida que se acerca el fin de siglo. Frente a las octavas de Bautista de Vivar, «Mártires son de Dios, que más ventura, / vida y ciencia del cielo y sus privados, / a do se trata sangre y se derrama, / sirviendo a Dios y al rey con honra y fama»;76 la loa de Rojas Villandrando, «faltan bagajes, falta alojamiento, / no hay barracas, garitas ni consuelo/aguas, nieves, granizos, sol y viento/rayos, truenos, calores, frío y hielo». ${ }^{77} \mathrm{Y}$ lo que es más significativo, entre los propios poetas soldados, como hemos visto, surge progresivamente una imagen más

\footnotetext{
74 La importancia de introducir «particulares» o caballeros ya era manifiesta desde el comienzo de la guerra, pues el duque de Alba en 1567 señalaba «gente de esta cualidad es la que da la victoria en las facciones y con la que el general pone en la gente la disciplina que conviene, y en nuestra nación ninguna cosa importa como introducir caballeros y gente de bien en la infantería y no dejalla toda en poder de labradores y lacayos» (citado por Parker, 2006, p. 75). Según B. Bennassar, op. cit, p. 314, el porcentaje de nobles era muy alto entre 1567-1577, y después desciende, lo que coincide con la denuncia de Rey de Artieda.

75 Rey de Artieda (1605), ff. 3v-4.

76 «Octavas a la vida militar» de Juan Bautista de Vivar (finales XVI), citadas por García Hernán, op. cit., p. 81.

77 Loa El viaje entretenido, de Agustín de Rojas Villandrando (1603), citada por García Hernán, op. cit., p. 92.
} 
negativa ${ }^{78}$ y desencantada de su oficio, y los poemas burlescos o llenos de desaliento sustituyen a los de exaltación y orgullo. ${ }^{79}$ Como señalaba Lara Garrido su exhaustivo estudio de los poemas de Aldana y de Virués:

La intensa y sostenida apreciación de la excelencia de lo militar, la conciencia sublimada de un destino al que se rinden como instrumento supremo, y la sacralidad misma de las empresas a las que entregan su servicio, aparecen veteadas [...] por fugaces pero también intensa depreciaciones [...] parentéticas incursiones en una escritura sarcástica, que bordea en algún caso la ironía trágica [...] un humor que neutraliza la envoltura trascendente para humanizar en gestos [...] la tremenda experiencia -la locura- de la vida en la milicia. ${ }^{80}$

No cabe duda de que la experiencia que Aldana y Rey de Artieda vivieron en la «Guerra de los Ochenta Años» marcó su concepción y su valoración de la vida del soldado, multiplicando las «depreciaciones»y las «incursiones» en el sarcasmo, la ironía o el humor, especialmente en el segundo de los poetas. La escasez de recursos para mantener las tropas, la dureza de los sitios, el frío del norte, la indisciplina de sus compañeros, los saqueos, y los motines, quitaron todo el heroísmo que la guerra podía tener (como lucha contra el protestantismo y como defensa del rey) y la cubrieron de lodo. Sin embargo, cada poeta soldado refleja una visión distinta. Ambos escriben «letras sin sol», pero mientras en Artieda se trata sólo de una ausencia física, en Aldana es también metafísica. ${ }^{81}$ El primero reacciona a las privaciones y al desorden con la ironía y la sátira; mientras el segundo acusa un mayor cansancio de la vida militar, y un mayor pesimismo, ${ }^{82}$ quizá por la desazón de no obtener ninguna merced a sus

\footnotetext{
78 Sólo en los poemas en los que se compara la vida del soldado con la del cortesano -casi siempre en epístolas morales, tanto de estos poetas soldados como de Virués-, la primera adquiere una dimensión positiva, mientras que en el resto de contextos simboliza los vicios y la peor dimensión del ser humano.

79 Contrasta con la conciencia de Rey de Artieda sobre la devaluación de la profesión militar, la defensa que realiza Cristóbal de Virués ante la mala fama de «caballos, toros, lobos y leones»: «jOh miserable suerte de soldados/de todo el universo aborrecidos/por desgracia y miseria dél tenidos/con mil impropios nombres denostados! [...] ¿A quién llamáis así, gente plebea?/A quien da reinos, cetros y coronas, /con su sangre ganándolo y sus vidas/ ¿A quién así llamáis? A quien se emplea/en guardaros haciendas y personas/de vuestras ambiciones perseguidas», citado por J. Lara Garrido (2000), p. 307.
}

80 J. Lara Garrido (2000), p. 309. Incluso en Virués, que parece el menos marcado por el desengaño de los tres poetas-soldados, hay poemas que muestran una visión negativa de la guerra, como en la alegoría en la que la Verdad y la Razón huyen de Marte, que termina diciendo de la vida militar que es «peor mil veces que la muerte» (p. 311-12) o los tercetos en que describe «la terrible rotura de conciencia/la desnudez, miseria, frío y hambre, /la falta de gobierno y de prudencia» (p. 314).

81 En la poesía de Rey de Artieda no aparece un anhelo de transformación, un deseo de cambiar de vida y mejorar así moralmente. En ambos poetas, como en Virués, aparece la progresiva toma de conciencia de la cara negativa del oficio militar, pero en la «Epístola a Arias Montano» se da un paso más allá, determinando que la única salida ante el desengaño sufrido es retirarse del mundo, dedicarse a la vida contemplativa y reencontrarse en la religión.

82 La vena satírica de Aldana aplicada a la vida militar parece encontrarse sólo en el «Diálogo entre la cabeza y el pie» (para otras muestras de su humor véase las «Octavas compuestas para la boda de su hermano mayor», Aldana, op. cit., 209-218. 
servicios. Sin duda, no es casual que sea en las epístolas en verso de estos autores donde aparecen más huellas de su experiencia flamenca, y reflexiones más concretas y directas sobre la vida militar, pues en palabras de Rosa Navarro:

[...] el tono distendido de algunas epístolas permite oír una voz cercana a la auténtica del poeta, no sólo moralizando, sino expresando sus congojas o su felicidad. Horacio como modelo, pero también la realidad colándose por los versos. ${ }^{83}$

Uno y otro fueron testigos de importantes victorias (contra los franceses en San Quintín, contra los turcos en Lepanto) y también de duras derrotas o frustrados intentos de ataque (el sitio de Alkmaar, la Gran Armada). No coincidieron en Flandes, pero sí en el «Parnaso literario», pues fueron elogiados por Gil Polo, Cervantes, ${ }^{84}$ Arias Montano, Lope de Vega, Quevedo, y otros escritores, que destacaron su doble valor en las armas y en las letras:

Tenga lugar el Capitán Aldana entre tantos científicos señores, que bien merece aquí tales honores tal pluma y tal espada castellana. ${ }^{85}$ (Lope de Vega sobre Aldana)

En ti dos graves Scevolas contemplo, uno del justo Marte favorido, otro de la que dio su nombre a Athenas. ${ }^{86}$ (Lupercio Leonardo de Argensola a Rey de Artieda)

Tú, a quien Marte le dio timbre y celada, para que armado al enemigo assombres, y Apolo el dulce título y renombres, con que a las Nimfas del Parnaso agrada. ${ }^{87}$ (Marcantonio Aldana ${ }^{88}$ a Rey de Artieda)

83 R. Navarro Durán, «Las epístolas de Francisco de Aldana: Diversificaciones del canon» en Grupo P.A.S.O., La epístola. Encuentros internacionales sobre poesía del Siglo de Oro, Sevilla, Universidad, 2000, pp. 199-220.

${ }_{84}$ M. de Cervantes, La Galatea, Madrid, Cátedra, 1995, dentro del "Canto de Calíope", p. 587, estrofa 102; y M. de Cervantes, Viaje del Parnaso, Madrid, Viuda de Alonso Martín, 1614, f. 19r. (edición digital de la Biblioteca Virtual Miguel de Cervantes).

85 F. Lope de Vega, Laurel de Apolo, Madrid, Iuan Gonçalez, 1630, Silva Sexta, f. 52 (edición digital de la Biblioteca Virtual Miguel de Cervantes). Como indica Rivers (1955), p. 37, «científico» equivalía a «filósofo», y el calificativo se explica por el interés de Aldana por el neoplatonismo y por la astrología, que muestra por ejemplo en sus «Octavas a la vida retirada».

86 Soneto de los preliminares de A. Rey de Artieda, Discursos, epístolas y epigramas de Artemidoro, Çaragoça, Angelo Tauanno, 1605, f. 3r. Ejemplar de la Universidad Complutense de Madrid digitalizado por Google Books. En el f. 97 aparecen otros dos sonetos a él atribuidos, sobre el engaño; y en el f. 99, sobre la esperanza. Forman parte de la tercera parte de sus obras, donde aparecen también traducciones de Petrarca, Aquilano, Alamani y Sannazaro.

87 Soneto de la misma obra, $\mathrm{f}$. $4 \mathrm{r}$.

88 Enric Querol, «Els Aldana, tortosins del segle XVI aveïnats a València: de les armes a les lletres», 
Otra conexión más entre estos poetas soldados es la aparición de un poema atribuido a «el único Aldana», las «Octavas a la muerte del príncipe don Carlos» ${ }^{89}$ en la edición de Rey de Artieda. Pero ante todo, lo que sin duda une a ambos es su descarnada descripción de la vida militar, la creación de imágenes en las que ambos verían reconocida su existencia. Resulta especialmente significativa la comparación de dichas imágenes en dos sonetos, «Otro aquí no se ve» $\mathrm{y}$ «Cruzar caminos»:

Otro aquí no se ve que, frente a frente, animoso escuadrón moverse guerra, sangriento humor teñir la verde tierra, $\mathrm{y}$ tras honroso fin correr la gente; éste es el dulce son que acá se siente: « ¡España, Santiago, cierra, cierra!», y por suave olor, que el aire atierra, humo de azufre dar con llama ardiente. El gusto envuelto va tras corrompida agua, y el tacto sólo apalpa y halla duro trofeo de acero ensangrentado, hueso en astilla, en él carne molida, despedazado arnés, rasgada malla. ¡Oh sólo de hombres dino y noble estado!

Francisco de Aldana ${ }^{90}$

\author{
Cruzar caminos, enfadar naciones, \\ mudar de camas, vinos diferentes, \\ ayres fríos, templados y calientes, \\ costumbres varias, varias opiniones; \\ desquilaxar serpientes y leones \\ (que es domar unas gentes y otras gentes) \\ rompiendo siempre por inconvenientes, \\ y siempre esclavo de las sinrazones, \\ os darán diez escudos de ventaja \\ pagados por la mano de un verdugo, \\ enemigo mortal del trato humano, \\ y a largos años, cuando el cielo plugo \\ que veáys parte dellos en la mano, \\ serán para comprar una mortaja.
}

Andrés Rey de Artieda o Antonio Vázquez ${ }^{91}$

Pedralbes, 27 (2007), pp. 199-218, deshaciendo la confusión entre los extremeños Aldana de Valencia de Alcántara y los valencianos de Tortosa, en la que incluso E. L Rivers (1955), p. 10, había caído, identifica a Marco Antonio Aldana (Tortosa, 1529?-1591), como el hijo de Joan de Aldana (que hizo prisionero al rey Francisco de Francia), que sirvió al duque de Cardona, y fue elogiado por Gil Polo en el «Canto del Turia» de la Diana enamorada (1565): «Este es Aldana, el único monarca/que junto ordena versos y soldados [...] en gran duda pondrán si él es Petrarca/o si Petrarca es él, maravillados/de ver que donde reyna el fiero Marte/tenga el facundo Apolo tanta parte». Aparece también un soneto preliminar suyo en La Carolea de Sempere (1560), y es propuesto por el duque de Sessa en 1584 como traductor de la obra de Maquiavelo. En cuanto al soneto que nos ocupa, Querol propone dos opciones: o que el autor sea un hijo del anterior; o que la obra de Rey de Artieda estuviera preparada para la impresión antes de que Aldana muriera, y por ello le encargara un poema laudatorio. Lo que parece claro es que no tiene ninguna relación con Francisco de Aldana.

${ }^{89}$ Aparece en Rey de Artieda (1605), f. 29v. y f. 30, seguida de una glosa de Rey de Artieda. Según Lara Garrido, en Aldana, op. cit., p. 504, de los muchos testimonios de este poema, ésta es la única atribución a Aldana, mientras que la más frecuente es la de Damasio de Frías. Quizá el apellido «Aldana» podría referirse al autor del soneto de los preliminares, Marcantonio Aldana, pero el epíteto «el único» parecería más apropiado para referirse a Francisco de Aldana, a quien según Cervantes (Viaje del Parnaso, f. 79v.) el epíteto "El Divino" estaba reservado junto con Garcilaso, Figueroa y Herrera.

90 Aldana, op. cit., p. 344.

91 Así dice el encabezamiento del soneto en Rey de Artieda (1605), f. 107v. Al mismo sargento Antonio Vázquez -que en la rúbrica de otro poema es capitán-, se le atribuye el soneto anterior, «Mientras por competir con tu cabello», que presenta algunas variaciones respecto al renombrado de Góngora. Aunque no hemos logrado identificar a Antonio Vázquez, no sería imposible que se tuviera relación con Alonso Vázquez, conocido por su obra Los sucesos de Flandes en tiempos de Alejandro Farnese (1577-1592), inédita hasta el siglo XIX, pero que gozó de difusión manuscrita pues es fuente de las obras de Lope y Calderón sobre Flandes, y se conserva un manuscrito dedicado a Felipe IV -según Vosters, el Ms. 2767 de la BNM-. Además de la semejanza en el nombre, y en que ambos fueron sargentos y capitanes, este último nace y muere en fechas casi exactas a las de Artieda, estuvo en Flandes en la misma época y bajo el mando de Parma, fue también soldado unos treinta años, y a su vuelta a España estuvo como él al servicio del virrey de Aragón. Parecen demasiadas coincidencias para ser casuales. 
Aunque uno las dibuje acentuando la intensidad y la extrema experiencia sensorial de la batalla y sus consecuencias, y el otro las aborde desde el humor y la ligereza, deteniéndose en las condiciones que rodean la guerra -no en la guerra misma y sus horrores-, la reflexión filosófica que subyace sobre el sinsentido de sus esfuerzos y sufrimientos como soldados parece similar. Aldana simboliza su condición de soldado en la herida sangrante, y Rey de Artieda o Antonio Vázquez (pues la autoría de este significativo soneto no está clara $)^{92}$ en la inseguridad, en el movimiento continuo, ${ }^{93}$ en la pobreza. Pero ambos símbolos presentan la vida del soldado como si no valiera la pena tanta violencia, tanto riesgo, como si ante la muerte, las posibles causas o motivaciones de la milicia -desde el reconocimiento hasta la paga- perdieran todo su valor por llegar demasiado tarde, tras haber, en cierto modo, malgastado su juventud. Son estos sonetos, como el resto de los poemas aquí estudiados, una aportación literaria a la historia de la guerra de Flandes, y su valor tanto documental como expresivo ha de reivindicarse, pues como señaló Lara Garrido:

Sólo en el espejo de la creación verbal se represan -y pueden ser captados- los relieves múltiples con los que la conciencia de sujetos varios, que se filtra a través de mediaciones ideológicas y retóricas [...] asume los códigos y experiencias de la guerra [...] Sólo ahí permanece indeleble la estrategia interior de pasiones, sentimientos, motivaciones y deseos $[\ldots] .^{94}$

\section{BibLiografía}

Alcalá-Zamora y Queiro de Llano, José, España, Flandes y el Mar del Norte (1618-1639), Barcelona, Planeta, 1975.

Aldana, Francisco de, Poesía, ed. Elias L. Rivers, Madrid, Espasa-Calpe, 1966.

Aldana, Francisco de, Poesías castellanas completas, Ed. de José Lara Garrido, Madrid, Cátedra, 1985.

\footnotetext{
92 Mientras Diane Chaffée-Sorace, en Góngora's poetic textual tradition. An analysis of selected variants, versions and imitations of his shorter poems, London, Tamesis, 1988, consideraba creíble la autoría de Vázquez, así como que Góngora fue quien le imitó en el soneto anterior; Biruté Ciplijauskaité, en su edición de los sonetos de Góngora, al recoger este testimonio, parece defender que se trata de una copia del famoso poeta, dado que nada se sabe de Vázquez. I. Osuna, op. cit., p. 236-237, no cuestiona la existencia de Vázquez, cuya inclusión en la edición, como la de otros personajes, atribuye a la dimensión social de la poesía, por la que los amigos de Artieda comentan o responden a sus ideas. Existen, por tanto, dos posturas, una a favor de la existencia real de un sargento y luego capitán Antonio Vázquez, y otra para la que éste sería un disfraz, una voz de Artieda. En ambos casos estaría justificado cerrar el análisis con este poema, ya que o bien pertenece a Artieda, o bien a un amigo cuya visión comparte.

93 Este mismo cansancio de los cambios y la inestabilidad de la vida militar aparecen en la obra de Aldana, por ejemplo en «En fin, en fin»: «tras tanto variar vida y destino», «tras tanto acá y allá yendo y viniendo», donde concluye anhelando retirarse del mundo y ser olvidado, como Hurtado de Mendoza en su horaciana epístola a Boscán. Aldana, op. cit., p. 429.
}

${ }_{94}$ Lara Garrido (2000), p. 344. 
Aldana, Francisco de, Poesía, Ed. de Rosa Navarro Durán, Barcelona, Planeta, 1994.

Alegre Peyrón, José MAría, «El ejército, gran protagonista de la política exterior de los Austrias españoles» en La espada y la pluma. Il mondo militare nella Lombardia spagnola cinquentesca. Atti del Convegno Internazionale di Pavia, Luca, Mauro Varoni, 2000, pp. 11-35.

Baranda, Nieves, «La Marfira de Ramírez Pagán: ¿Otra mujer poeta del siglo XVI?» en Actas del XIII Congreso de la Asociación Internacional de Hispanistas, tomo I, Madrid, Castalia, 2000, pp. 272-281.

Bennassar, Bartolomé, La España del Siglo de Oro, Barcelona, Crítica, 1983.

Cabello Porras, Gregorio, «Las Varias poesías (1591) de Hernando de Acuña: de Garcilaso a Boscán. El tránsito del humanismo militar a la "nueva lengua poética"», Dicenda. Cuadernos de Filología Hispánica, vol. 26 (2008), pp. 5-61.

Cervantes Saavedra, Miguel de, Viaje del Parnaso, Madrid, Viuda de Alonso Martín, 1614 (edición digital de la Biblioteca Virtual Miguel de Cervantes).

Cervantes SaAvedra, Miguel de, La Galatea, ed. F. Estrada y M. T. López, Madrid, Cátedra, 1995.

Ciplijauskaité, Biruté, Introducción a Luis de Góngora, Sonetos completos, Madrid, Castalia, 1988.

Chaffée-Sorace, Diane, Góngora's poetic textual tradition. An analysis of selected variants, versions and imitations of his shorter poems, London, Tamesis, 1988.

Echevarría, Miguel Ángel, Flandes y la Monarquía Hispánica. 1500- 1713, Madrid, Sílex, 1998.

Ferrer, Teresa, Teatro clásico en Valencia I, Madrid, Biblioteca Castro, 1997.

García Aguilar, Ignacio, «Cosme edita a Francisco de Aldana: problemas de la edición póstuma» en Pedro Ruiz Pérez, Cánones críticos en la poesía de los Siglos de Oro, Vigo, Academia del Hispanismo, 2008, pp. 191-206.

García García, Bernardo y Barsace, Alain, coord. Hazañas bélicas y leyenda negra: argumentos escénicos entre España y los Países Bajos: Coloquio Internacional, Béthune, 25-26 de marzo de 2004, Madrid, Fundación Carlos de Amberes, 2005.

GARCíA-Hernán, DAvid, La cultura de la guerra y el teatro del Siglo de Oro, Madrid, Sílex, 2006.

Huarte de San Juan, Juan, Examen de ingenios para las ciencias, Madrid, La Rafa, 1930 (edición digital de la Biblioteca Virtual Miguel de Cervantes).

JimÉNEz Ruiz, José, «La poesía epistolar de Andrés Rey de Artieda: nuevos modos de un género clásico», Canente: revista literaria, n. 3-4, (2002), pp. 279-304.

LARA GARrido, José, Introducción a Poesías castellanas completas de Francisco de Aldana, Madrid, Cátedra, 1985.

LARA GARRIDO, José, «Las ediciones de Francisco de Aldana: hipótesis sobre un problema bibliográfico», Revista de estudios extremeños, Vol. 42, No 3 (1986), pp. 541-584. 
Lara Garrido, José, «" Palma de Marte" y “lauro de Apolo": la poesía del "oficio militar" en Francisco de Aldana y Cristóbal de Virués» en La espada y la pluma. Il mondo militare nella Lombardia spagnola cinquentesca. Atti del Convegno Internazionale di Pavia, Luca, Mauro Varoni, 2000, pp. 281-347.

Lefebvre, Alfredo, La poesía del Capitán Aldana (1537-1578), Concepción, Universidad, 1953.

Lope De VeGA, Félix, Laurel de Apolo, Madrid, Iuan Gonçalez, 1630 (edición digital de la Biblioteca Virtual Miguel de Cervantes)

Losada, Juan Carlos, Los generales de Flandes. Alejandro Farnesio y Ambrosio de Spinola, Madrid, La Esfera de los libros, 2007.

Martínez López, María José, «La primera redacción de las Octavas dirigidas a Felipe II de Francisco de Aldana y su inédita dedicatoria en prosa», Criticón, $\mathrm{n}^{\circ} 70$ (1997), pp. 31-70.

Navarro Durán, Rosa, «Las epístolas de Francisco de Aldana: Diversificaciones del canon» en Grupo P.A.S.O., La epístola. Encuentros internacionales sobre poesía del Siglo de Oro, Sevilla, Universidad, 2000, pp. 199-220.

Osuna, InMACULADA, «Las epístolas de Artemidoro (Andrés Rey de Artieda)» en Grupo P.A.S.O., La epístola. Encuentros internacionales sobre poesía del Siglo de Oro, Sevilla, Universidad, 2000, pp. 233-55.

Parker, Geoffrey, El ejército de Flandes y el Camino Español. 1567-1659, Trad. de Manuel Rodríguez Alonso, Madrid, Alianza Universidad, 1985; y edición revisada y ampliada, Madrid, Alianza, 2006.

Parker, Geoffrey, España y la rebelión de Flandes, Trad. de Gonzalo Gil Catalina y José Luis Gil Aristu, Madrid, Nerea, 1989.

Pazzis Pi Corrales, Magdalena De, «Pedro de Valdés y la Armada de Flandes», Cuadernos de Historia Moderna, $\mathrm{n}^{\circ} 9$ (1988), pp. 35-45.

QUEROL, ENRIC, «Els Aldana, tortosins del segle XVI aveïnats a València: de les armes a les lletres», Pedralbes, 27 (2007), pp. 199-218.

Rey de ArTIEDA, Andrés, Discursos, epístolas y epigramas de Artemidoro, Çaragoça, Angelo Tauanno, 1605.

Rey de Artieda, Andrés, Discursos, epístolas y epigramas de Artemidoro, Ed. de Antonio Vilanova, Barcelona, Selecciones Bibliófilas, 1955.

Rivers, EliAs. L., Francisco de Aldana, el divino capitán, Badajoz, Institución de Servicios Culturales, 1955.

Rivers, Elias. L., «La epístola en verso del Siglo de Oro», Revista Draco de la Universidad de Cádiz, no 5-6 (1993-4), pp.13-31.

Rodríguez-Salgado, M.J., Un imperio en transición. Carlos V, Felipe II y su mundo, Trad.de Juan Faci, Barcelona, Crítica, 1992. 
Letras sin sol: la visión de Flandes en dos poetas soldados del renacimiento español

Vilanova, Antonio, Introducción a Discursos, epístolas y epigramas de Artemidoro, Barcelona, Selecciones Bibliófilas, 1955.

Vosters, Simon A., La rendición de Breda en la literatura y el arte de España, London, Tamesis, 1973. 